\title{
熱可塑性エラストマーーTPSとTPOを中心に一-
}

\author{
加 藤 清 雄*

\section{Recent Advances in Thermoplastic Elastomer in Japan. -Application, Market and Material-}

Kiyoo KATO (Asahi Kasei Chemicals Corporation, Synthetic Rubber Division, Technical and Development Department of Synthetic Rubber 1-3-1 Yako, Kawasaki-ku, Kawasaki, Kanagawa 210-0863, JAPAN)

Recent advances in Thermoplastic Elastomer in Japan are described, and trends of application, market and material development in the future are also forecasted.

TPEs global market is growing with 8-10\% /year in this decade. Although the growing rate in Japan is not so high as that in the world, the trend will succeed also in Japan.

Especially, TPOs and hydrogenated TPSs (SEBS, SEPS) are growing very fast. TPOs based on metallocene catalyzed technology is very unique. Many TPOs of which structure (tacticity, narrow molecular weight distribution and block sequences) is well regulated, are developed for automotive materials, sheets and films applications. Also blend type of TPOs, especially TPVs have been well developed and commercialized.

Many grades of hydrogenated TPS are developing. The wide applications of the low and middle molecular weight type of hydrogenated TPS are thermoplastic modifier, adhesive, and compatibilizer for TPV, engineering plastics and polymer blends. High molecular weight type of hydrogenated TPS are well used for TPS elastomer compound which is used for automotive, liner cap of beverage, medical bag and medical tube. TPVs are growing because of its heat stability and oil resistance. New types of TPV named super-TPV are also developing. The global growth of TPE will be continued for next decade.

Key Words : Thermoplastic Elastomer, Hydrogenated, TPS, TPO, Metallocene, Automotive, TPV, Compatibilizer

\section{1. 概 況}

熱可塑性エラストマー (以下 TPE) は, 加硫, 化学的架 橋を行わずにゴム状弾性を発現する共重合体である，加熱 すると流動するため容易に熱可塑性樹脂と同様の成形加工 が可能であり，常温ではゴム状弾性を示す，TPEを分子 構造で分けると(1)スチレン系(TPS)(2)オレフィン系(TPO) (3)塩ビ系 (T-PVC) 4)ウレタン系(TPU)(5)ポリエステル系 (TPEE)(6)ポリアミド系(TPAE) (7)その他となる.

TPEは世界で過去数年間に $8 \sim 10 \%$ ，特にTPOの動的 架橋タイプ(TPV) と TPSの一種の水添系 TPS (SEBS · SEPS) は 2 标の成長 ${ }^{1)}$ をている. また, 最近のナフサ 高騰による原材料価格の上昇を反映して新しい加工技術を 利用し，付加価值を高めるTPEが目立っている ${ }^{1)}$. 例え ば大型部品の 2 ショット成形, 薄肉で複雑な形状をしたチ ユーブの吸引ブロー成形, 高機能ブーッ／蛇腹の 3 次元ブ ロー成形, 連続的に行われるバルブのゲート制御等である. TPEの国内需要は自動車, 建材, スポーッ, 医療用途,
工業部品等の分野で急成長を遂げ, 現在でも堅調に推移し ている. 20 年前のゴム技術フォーラムでゴム工業の今後 の発展について上記用途分野の将来予測 ${ }^{2)}$ をているが, TPE はこれら用途に着実に進出・拡大していることから 当時の市場予測が的確だったことがわかる.

表 1 に TPE種類別の 1986年当時の国内需要 ${ }^{2)}$ と2006年 の国内メーカーの国内販売量 ${ }^{3)}$ (TPS 以外は国内メーカー の輸出を含む販売量)を記した. 国内需要と国内メーカー 販壳量であるため 20 年間の差異を単純比較はできないも のの, T-PVC以外はこの 20 年間で著しい伸長をみせてい ることが理解できる.

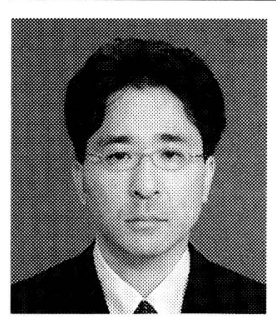

*旭化成ケミカルズ侏合成ゴム事業部 合成ゴ 厶技術開発部（２２10-0863 川崎市川崎区夜 光 1-3-1) 部長. 1983 年東京工業大学総合理 工学研究科修了. 同年旭化成工業侏入社, 現 在に至る. 専門は合成ゴム, 熱可塑性エラス トマー, ポリマーアロイ. SPE (Society of Plastic Engineers) 日本支部理事. 
表 1 TPE の種類 ${ }^{2)}$ と 20 年間の国内市場の伸び

\begin{tabular}{|c|c|c|c|c|}
\hline 分類 & 拘束様式 & 軟質相 & 1986 年当時の国内需要 ${ }^{2)}(千 \mathrm{t} / \mathrm{y})$ & 2006 年の国内メーカー販売量 ${ }^{4)}($ 千 $\mathrm{t} / \mathrm{y})$ \\
\hline \multirow[t]{2}{*}{ スチレン系 } & \multirow{2}{*}{$\begin{array}{l}\text { 凍結相 } \\
\text { PS }\end{array}$} & BR, IR & 20 & 78(国内販売のみ) \\
\hline & & $\begin{array}{l}\text { 水添 } \mathrm{BR} \\
\text { 水添IR } \\
\text { 水添 } \mathrm{BIR}\end{array}$ & 資料なし & 19(国内販売のみ) \\
\hline \multirow[t]{2}{*}{ オレフイン系 } & \multirow[t]{2}{*}{$\begin{array}{l}\text { 結晶相 } \\
\text { PP, PE }\end{array}$} & $\begin{array}{l}\text { EPDM } \\
\text { EPM, NR } \\
\text { EOM, EBM }\end{array}$ & 23 & 190 (輸出含む) \\
\hline & & SEBS, SEPS & 資料なし & 11(国内販売のみ) \\
\hline 塩ビ系 & $\begin{array}{l}\text { 結晶相 } \\
\text { 結晶PVC }\end{array}$ & 非結晶PVC & $19 \sim 20$ & 23 (輸出含む) \\
\hline ウレタン系 & $\begin{array}{l}\text { 水素結合 } \\
\text { 及び結晶相 } \\
\text { ウレタン構造 }\end{array}$ & $\begin{array}{l}\text { ポリエステル } \\
\text { ポリエーテル } \\
\text { ポリカーボネート }\end{array}$ & 7.5 & 18(輸出含む) \\
\hline ポリエステル系 & $\begin{array}{l}\text { 結晶相 } \\
\text { ポリエステル } \\
\text { (PBT) }\end{array}$ & $\begin{array}{l}\text { ポリエーテル } \\
\text { ポリエステル }\end{array}$ & 2.7 & 11 (輸出含む) \\
\hline ポリアミド系 & $\begin{array}{l}\text { 結晶相 } \\
\text { 水素結合 } \\
\text { ポリアミト }\end{array}$ & $\begin{array}{l}\text { ポリエーテル } \\
\text { ポリエステル }\end{array}$ & 0.5 & 1.6 (輸出含む) \\
\hline ポリブタジエン系 & $\begin{array}{l}\text { 結晶相 } \\
\text { syn-1,2-BR }\end{array}$ & 非結晶 BR & 資料なし & 30 (輸出含む) \\
\hline フッ素系 & $\begin{array}{l}\text { 結晶相 } \\
\text { フッ素樹脂 }\end{array}$ & 非晶フッ素ゴム & $0.1 \sim 0.2$ & 0.5 (輸出含む) \\
\hline
\end{tabular}

表 2 各TPEの特徵と課題

\begin{tabular}{|c|c|c|}
\hline & 特 & 課 \\
\hline TPS & ゴム弾性, 低温特性, 軽量化 & 熱安定性, 耐油性, リサイクル性 \\
\hline TPO & 耐熱・耐寒性, 耐候性, 耐老化性, 軽量化,リサイクル性 & 耐傷つき性 \\
\hline $\mathrm{T}-\mathrm{PVC}$ & 圧縮永久ひずみ, 反発弾性, 屈曲疲労, 強度, 耐摩耗性, 耐傷付性 & 環境問題（非ハロゲン） \\
\hline TPU & 機械的特性, 低温特性, 耐摩耗性, 耐油性 & 耐熱性, 耐水性, 硬度, コスト \\
\hline TPEE & 耐熱性, 耐候性, 耐屈曲性, 温度領域の広さ, 耐油性, 耐薬品性 & 圧縮永久ひずみ, 硬度, コスト \\
\hline TPAE & 軽量化, 成型加工性, 耐加水分解性, 熱安定性, 耐薬品性 & PA 6 等と比べたときの耐熱性低下, 吸水性, 強勒性, コスト \\
\hline
\end{tabular}

ここ最近の国内メーカーTPE種類別の販売量推移と 2007 年予想 ${ }^{3)}$ をTPS (国内販売のみ：図 $1-1$ ), TPO (図

\section{スチレン系TPE国内販売器}

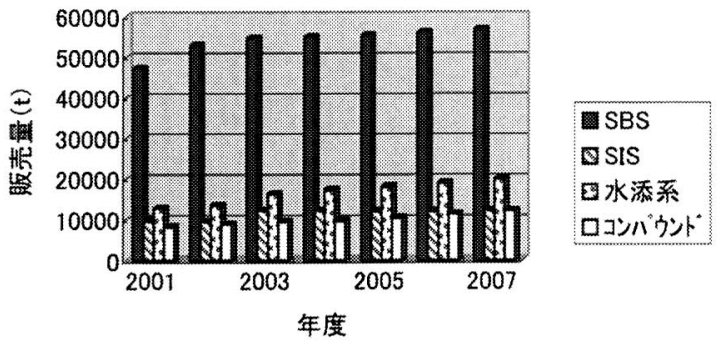

図 1-1 国内メーカーのTPSの販売量推移

オレフイ系TPE販売量

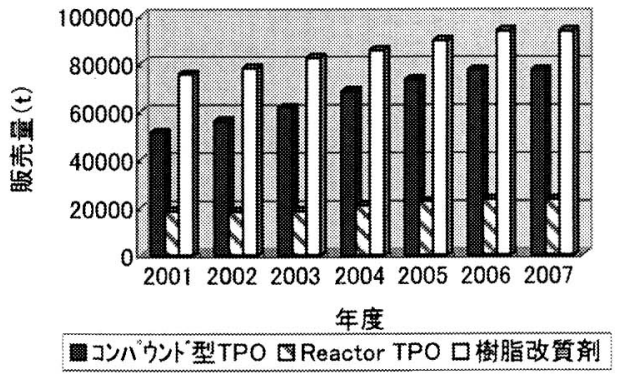

図 $1-2$ 国内メーカーのTPOの販売量推移
$1-2$ )，T-PVC及びエンプラ TR(図 $1-3$ ) 別にそれぞ れ示す.

TPS，TPO は環境規制の整備を背景に塩ビや合成ゴム の代替材料として需要が拡大傾向にあり, 幅広い分野で需 要が堅調に推移している。

2005 年度の国内自動車生産台数は 1089 万台と 4 年連続 のプラス成長 ${ }^{3)}$ を示した。今後の自動車分野でのアジア を中心としたTPE需要の動向を既存用途と塩ビや架橋合 成ゴムの代替に分けると前者では今後も安定的な需要が期 待される。しかし塩ビ代替はコスト的・性能・技術的に困 難も多く, 可能な部分の代替はほぼ完了している.また加

塩ビ系、エンプラ系TPE

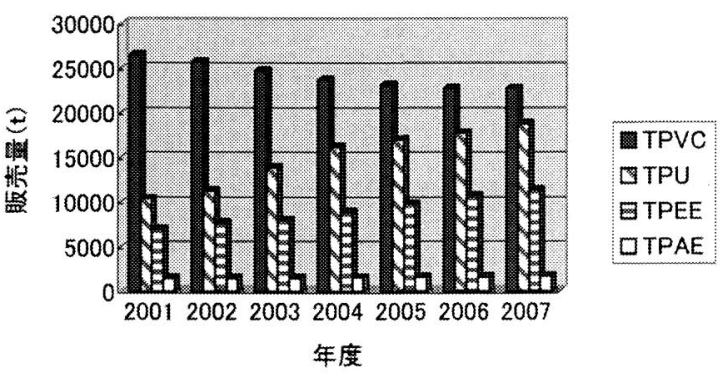

図 $1-3$ 国内メーカーの T-PVC, エンプラ TRの販売量推移 
表 3 主要 TPEの分類別用途 3$)$

\begin{tabular}{|c|c|c|c|c|c|c|}
\hline & TPS & TPO & T-PVC & TPU & TPEE & TPAE \\
\hline 自動車 & $\begin{array}{l}\text { 表皮材, ホース類, エア } \\
\text { バックカバー, バンパー } \\
\text { PP改質 }\end{array}$ & $\begin{array}{l}\text { マッドガード, バンパー } \\
\text { ブーツ, エアホース, 内 } \\
\text { 装表皮材, グラスランチ } \\
\text { ヤネル, ウェザーストリ } \\
\text { ップ, エアバックカバー, } \\
\text { ラック\&ピニオンブー } \\
\text { \% CVJブーッ }\end{array}$ & $\begin{array}{l}\text { ウェザーストリップ, パ } \\
\text { ッキン類, ダクトカバー }\end{array}$ & $\begin{array}{l}\text { ブーツ類, ショックアブ } \\
\text { ソーバ,パッキン類, パ } \\
\text { ネル, スノーチェーン }\end{array}$ & $\begin{array}{l}\text { R\&Pブーツ, CVJ ブー } \\
\text { ツ }\end{array}$ & パーキングケーブル, カバー \\
\hline 家電·弱電 & \begin{tabular}{|l|} 
電線ケーブル, プラグ類, \\
プロテクトフィルム
\end{tabular} & $\begin{array}{l}\text { ホース, パッキン類, 足 } \\
\text { ゴム, 電線ケーブルプロ } \\
\text { テクト }\end{array}$ & $\begin{array}{l}\text { 電線ケーブル, ホースパ } \\
\text { イプ, プロテクト, パッ } \\
\text { キン類 }\end{array}$ & 電線ケーブル & $\begin{array}{l}\text { ギヤ類, ホース, プロテ } \\
\text { クト,パッキン, キーパ } \\
\text { ッ゙, カールコード }\end{array}$ & $\begin{array}{l}\text { 消音ギヤ, 電線被覆キーボー } \\
\text { ドカバー }\end{array}$ \\
\hline 工業用品 & $\begin{array}{l}\text { パッキン類, ノブ, マッ } \\
\text { ト, ガーデンホース, キ } \\
\text { ヤスター }\end{array}$ & ベルト, 工具グリップ & $\begin{array}{l}\text { ダクトホース, サクショ } \\
\text { ンホース, ガーデンホー } \\
\text { ス }\end{array}$ & $\begin{array}{l}\text { ホース, チューブ, ベル } \\
\text { ト, ローラ, カメラダリ } \\
\text { ップ }\end{array}$ & ホース, チューブ & \\
\hline 土木·建築 & $\begin{array}{l}\text { アスファルト改質, クラ } \\
\text { フトテープ, ローラクリ } \\
\text { ーチ, 床材 }\end{array}$ & $\begin{array}{l}\text { 止水シート・マット,ガス } \\
\text { ケット }\end{array}$ & $\begin{array}{l}\text { 止水シート, シール, ガ } \\
\text { スケット類, マット }\end{array}$ & シート・フィルム & 橋梁用緩衝材 & \\
\hline $\begin{array}{l}\text { スポーツ用品 } \\
\text { ・雑貨 }\end{array}$ & $\begin{array}{l}\text { シューズ用ソール, ゴー } \\
\text { グルバンド, ストックグ } \\
\text { リップ, 粘接着剤 }\end{array}$ & $\begin{array}{l}\text { ローラ, スポーツ用品・ } \\
\text { 文具·工其用グリップ, } \\
\text { アクアランプ, フィルム }\end{array}$ & $\begin{array}{l}\text { 玩具類, 文具類, 置物, } \\
\text { 人形, フイルム }\end{array}$ & $\begin{array}{l}\text { シューズ用ソール，時計 } \\
\text { バンド }\end{array}$ & $\begin{array}{l}\text { シューズ用ソール, ボー } \\
\text { ル内袋, エアレスチュー } \\
\text { ブ }\end{array}$ & $\begin{array}{l}\text { シューズ用ソール， スキーブ } \\
\text { ーツ }\end{array}$ \\
\hline $\begin{array}{l}\text { 医療・ヘルス } \\
\text { ケア }\end{array}$ & $\begin{array}{l}\text { 紙拈むつ, 注射器シリン } \\
\text { ジ,ガスケット, 血液バ } \\
\text { ック・チューブ }\end{array}$ & $\begin{array}{l}\text { 歯ブラシ柄, グロメット } \\
\text { 採血管ギャップ }\end{array}$ & $\begin{array}{l}\text { 輸血バック, 輸血チュー } \\
\text { ブ }\end{array}$ & コンドーム & ヘアブラシ & カテーテル \\
\hline 樹脂改質 & $\begin{array}{l}\text { PP·PS · PPE改質, 相 } \\
\text { 容化剂 }\end{array}$ & & & PVC, ABS, POM改質 & 他樹脂ブレンド & ナイロン改質ほか \\
\hline その他 & 不織布 & 軟質PVC代替材 & & $\begin{array}{l}\text { 手袋コーティング, 不織 } \\
\text { 布 }\end{array}$ & & \\
\hline
\end{tabular}

硫EPDMのリサイクルも積極的になされており，ゴム代 替の流れも一巡した ${ }^{4)}$ 感もある. 今後の需要拡大には環 境対応や安定供給にも配慮した信頼性のある材料開発とコ ストダウンが必要になろう. 表 2 に各TPEの特徽と課題 を，また表 3 には主要TPEの分野別用途3,4）を示した。

以下 TPE種別に発展と展望について述べるが，特に高 成長が期待される水添系 TPS と TPOを詳述する.

\section{2. 各種 TPEの素材・用途開発の進歩}

\subsection{TPS}

\section{1 .1 中低分子量TPS}

TPEの中で最も加硫ゴムらしいといわれるTPSは靴底, 粘接着剂, アスファルト改質材, $\mathrm{PS} \cdot \mathrm{PP}$ 等各種樹脂改質 材等に使われる。TPSの 2005 年の国内市場規模はSBSで $55,400 t$, SIS で 12,100t, 水添系 (SEBS, SEPS 等) 18,200t の合計 $85,700 \mathrm{t}^{3,4)}$ になったとみられる. SBSの国内販売量 は近年 $2 \sim 3 \%$ 程度と大きな伸びは見られない.またSIS もテープ需要に大きな伸びが見られず，横這いである(図 $1-2)$. SISはSBSと比べて溶融粘度・保持力・夕ック 等のバランスに優れ，粘接着剂用途で多く使われている. 国内各社は汎用TPSの増産より高付加価值用途の市場開 拓に注力している.

SISはスチレン量やジブロック率を変量し, ホットメル ト型粘接着剂に使われているが，タック改良にはこれら構 造を変えることのみでは解決が困難である，日本ゼオンは タック改良を目的に低分子量ポリイソプレンを導入した 「クインタック」新グレードを展開5）している. SIS中で 低分子量ポリイソプレンは油滴のように独立相を形成して いると推定され, 柔軟性や変形除去後の復元力に関係して
いる5）と考えられている.

水添系 TPS はPP, PS, PPE等の樹脂改質や, 射出成形 用TPS コンパウンド用途への展開が中心であり，塩ビや 加硫ゴム代替によって国内需要年率 $5 \%$ 以上 (図 $1-4$ ), 海外で $10 \%$ 以上 ${ }^{1)}$ の伸長で推移している. 水添系TPSは 国内では $18,000 \mathrm{t}$ 程度 $^{3)}$, 世界で $110,000 \mathrm{t}$ 程度の市場がある と推定される。水添TPSは耐候性, 耐熱老化性, 耐摩耗 性に優れる. SEBS, SEPS, HSBR等があるが，新グレー ドやこれら以外にも様々な構造・機能を有するポリマーが 各社から次々と開発されている.

SEBS, SEPSの水添前の側鎖二重結合 (ビニル量) 比率 を制御し, 溶解度パラメーターを変えることでポリオレフ インへの相溶性を制御できる.ソフトセグメント中のビニ ル量が大きくなるとガラス転移温度が上昇し, かつ PP と の親和性が向上するため, PP ブレンド物に制振性や軟質 性を付与できる. 代表的なものに高ビニル型のSIS ・その 部分水添タイプであるクラレの「ハイブラー」やJSRの 「ダイナロン」(高ビニル HSBR), 旭化成ケミカルズの

\section{水添系TPSとTPSコンパウンド国内販壳量}

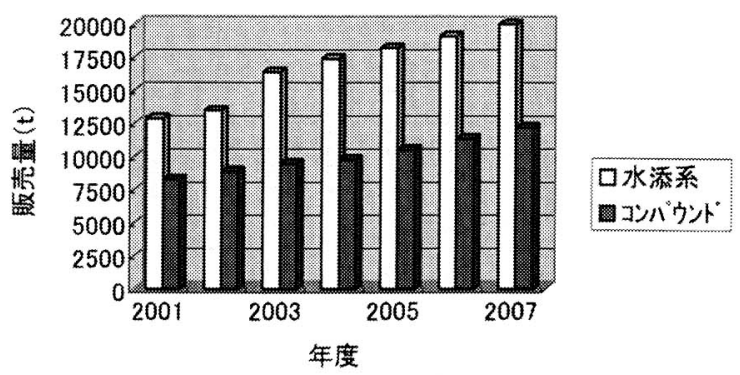

図 1-4 国内水添系 TPS および水添系TPS コンパウンドの販売量 推移 (国内販売のみ) 
「タフテック」（高ビニル SEBS）がある．また，ビニル量 の選択により SEBSはPP オオレフィンゴムの相容化剂兼 改質剤となり, PP系樹脂の低温性能・伸び改質剤として 広く用いられている.

TPSには分類されないが，水添系のCEBCやSEBCが JSRから上市されている.Cは低ビニル量の水添ポリブタ ジエンであり, LLDPE構造に近く, 結晶性を有する.こ のため PEとの親和性があり, LLDPE, PE, PP, PS 等の 相容化剂・改質剤となる。

水添系 TPS はPS, PC, PBT, PPE, TPU等の芳香族 系ポリマーとも親和性があるため, これら樹脂同士, ある いはこれら樹脂とポリオレフィンとの特殊コンパウンドの 相容化剂にも用いられている.

SBSのポリブタジエン部のビニル結合のみを選択水添し たSBBSはSEBSの基本的な性能を保持し, 秩序一無秩序 転移温度が完全水添型より低いために流動性に優れ，かつ 低温特性, 架橋性にも優れるため, 粘接着剂, 樹脂改質剂, 架橋発泡体等に使われている.

リビングカチオン重合法によりポリスチレンブロック， ポリイソブチレンブロックを導入した新しいブロックポリ マー,「SIBSTAR」をカネカが開発している ${ }^{6)}$ をソフトセ グメントに残存二重結合を全く含まず，耐熱老化性に優れ ること, ソフト骨格に起因するバリア性, 制振性, 柔軟性 を有し，新用途開発を展開中である.

\subsubsection{TPS コンパウンド}

高分子量のSEBS · SEPS · SEEPS(水添SIBS) 等はPP, オイル, 必要に応じて他樹脂等と溶融ブレンドすることで TPS系コンパウンドに使われる. TPS系コンパウンドは PPのマトリクス中に水添TPSが均一分散している。これ はTPVのモルホロジーと同じであり, TPSコンパウンド の拘束相はPSではなくPPの結晶相と考えることができる のでTPOに分類される(表 1 ).

TPS系コンパウンドの耐熱性向上にはPPEブレンド, 耐熱・耐油性向上には動的架橋やエンプラブレンド等がな されている.

TPS コンパウンドの国内メーカーの 2005年度販売量 ${ }^{3,4)}$ は約 $11,000 \mathrm{t}$, 対前年比 $7.7 \%$ 増と推定され, 大幅な成長を 見せている (図 $1-4)$. 塩ビ代替材料としての需要増に加 え, 加硫工程がなく生産性が高い, 悪臭がない, 着色の自 由度が大きいといった特徵を生かし, 加硫ゴム代替で量を 伸ばしている，最大の需要分野は医療用途である. 図 2 に TPS コンパウンドの販売量推移を示す. PETボトル用キ ヤップライナー材, パソコン電気系統材料, 電線被覆材等 の家電・OA分野がこれに次ぐ. 医療・食品用途は一般的 な性能に加えて医療衛生性・食品衛生性が要求されるが, 他材料では得にくく，このためTPSコンパウンドが多く 用いられている。自動車分野が急激に伸びたのは動的架橋
TPSコンパウンド需要别販売曡推移

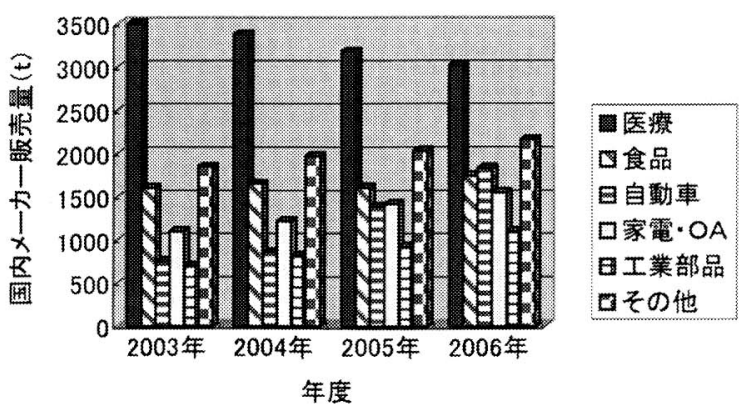

図 2 TPS コンパウンドの国内販売量推移

型の TPS コンパウンド出現のため ${ }^{3)}$ である. SEBS又は SEPS タイプのTPSを動的架橋でPP中に分散させたもの で耐熱性や耐薬品性, 圧縮永久ひずみが改良されている. スチレン末端ブロックを選択的に架橋したタイプも KRAIBURGから上市されている.また, TPS型TPVと TPU とのアロイは極性樹脂基材への接着性を改良した変 性動架橋TPSとして展開されている.

\subsubsection{TPS コンパウンド原体用高分子量TPS}

TPS コンパウンド用原体は高分子量 SEBS, SEPS, SEEPSが使われる。これらはクレイトンポリマー, クラ レ等から販売されており, 旭化成ケミカルズも現在上市検 討中である.

ここ数年で, 新しい構造を有する高分子量TPSが開発, 上市検討されている.クラレはSEEPSでハードセグメン 卜が架橋可能な製品7)を開発した。特許からパラメチル スチレンとスチレンのコポリマーがハードブロックと推定 される、パーオキサイドでソフトのみならずハードも架橋 可能で耐油性・耐熱性が向上する，特に長期的な高温圧縮 永久ひずみに優れることが特徵である。クレイトンポリマ 一は「クレイトン A」を開発した. 特許からスチレンブロ ックとスチレン/水添ブタジエンを含むソフトブロックを 持っていると推定される. 特徵は流動性, 寸法安定性, 極 性樹脂との融着性を挙げている。低分子量体と高分子量体 があり，TPSコンパウンドとしたときに広範囲のせん断 変形加工に対応できる. 旭化成ケミカルズでは高スチレン タイプの HSBRである「SOE-SS」を既に上市しているが， TPS コンパウンドの耐傷付性，圧縮永久ひずみを非架橋 で塩ビ以上に改質できる改良グレードを上市検討してい る. 高分子量SEBS, PP との相互作用を高める構造を分 子鎖に導入しており，SEBSとのハイブリッドコンパウン ド用の原体としての使用が推奖される.

\subsection{TPO}

TPO はコンパウンド型, リアクター型, 樹脂改質用オ レフィンエラストマーの 3 種類に分けられる。 それぞれに ついて最近の動向について説明する. 
表 4 オレフィン系エラストマーの主要製品 ${ }^{4)}$

\begin{tabular}{|c|c|c|c|c|}
\hline & 種類 & グレード名 & 密度 $\left(\mathrm{g} / \mathrm{cm}^{3}\right)$ & 特徵 \\
\hline \multirow{5}{*}{ タフマー } & エチレンー $\alpha$ オレフィン共重合体 & タフマーA & 0.885 & \multirow{4}{*}{$\begin{array}{l}\text { (1)非晶または低結晶ポリオレフィンで, 低温領域でも優れた柔軟性 } \\
\text { (2)無色透明, 屈折率も他のオレフィンと秀ないでレンド品の透 } \\
\text { 明性低下がない. } \\
\text { (3)各種ポリオレフィンとの親和性に優れ, ドライブレンドで成型可能 } \\
\text { (4)均質性に優れ, ゲルフリーなためフィシュアイのないフィルム成 } \\
\text { 型可能 } \\
\text { (5) PEやPP 同様, 耐熱老化性・耐候性に優れる }\end{array}$} \\
\hline & & タフマーP & 0.870 & \\
\hline & $\begin{array}{l}\text { プロピレン- } \alpha \text { オレフィン共 } \\
\text { 重合体 }\end{array}$ & タフマーXR & 0.89 & \\
\hline & $\begin{array}{l}\text { 1-ブテンホモポリマー及びコ } \\
\text { ポリマー }\end{array}$ & タフマーBL & $0.900-0.915$ & \\
\hline & $\begin{array}{l}\text { プロピレンー } \alpha \text { オレフィン共 } \\
\text { 重合体 (メタロセン) }\end{array}$ & タフマーXM & & $\begin{array}{c}\text { (1)メタロセン系のため, XRに比べて分子量分布が均質. } 25-35^{\circ} \mathrm{C} \text { の } \\
\text { 低融点化が可能. ヒートシール性良好. 耐ブロッキング防止効果. }\end{array}$ \\
\hline \multirow[t]{2}{*}{ エンゲージ } & $\begin{array}{l}\text { エチレン・1-オクテンコポリ } \\
\text { マー (EOM) }\end{array}$ & & $0.857-0.910$ & \multirow{2}{*}{ 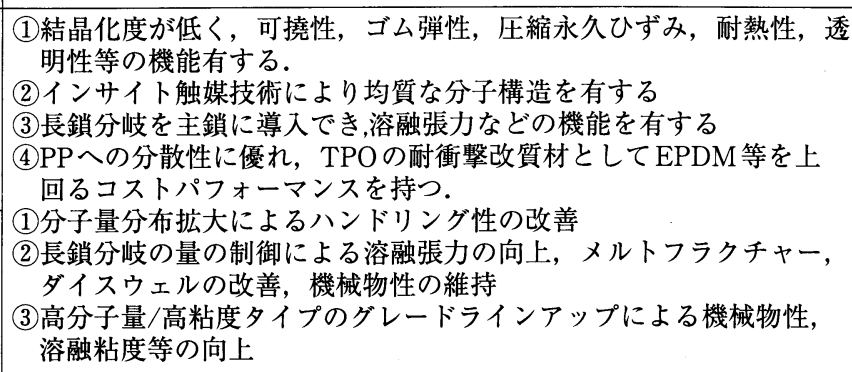 } \\
\hline & $\begin{array}{l}\text { エチレン・1-ブテンコポリマ } \\
\text { - }(\mathrm{EBM})\end{array}$ & & $0.857-0.905$ & \\
\hline
\end{tabular}

\subsection{1 コンパウンド型TPO}

TPO はハードセグメントにPPあるいは PE，ソフトセ グメントにEPDMあるいはEPMを主に使用したTPEで ある．さらにコンパウンド型 TPOは単純ブレンド(非架橋 タイプ) と動的架橋 (全面架橋, 部分架橋タイプ)に分けら れる. 動的架橋タイプは特に TPV と呼ばれ, 引張り強度 や永久伸び，耐油性が単純ブレンド系に比べて向上する.

コンパウンド型TPO は自動車分野が総需要の $70 \%$ 程度 を占める．TPOの課題であった耐傷付性，圧縮永久ひず みの改良がオレフィン型TPVで精力的に行われ，最近の

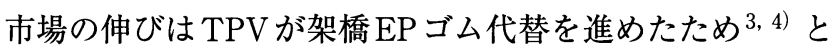
考えられる. PP/EPDM, PP/NBR, PP/NR, PE/EPDM, アクリルゴム/PP, IIR/PP, スチレン系 TPS/PPが開発・ 上市されている ${ }^{8)}$. 動的架橋には主に過酸化物架橋, フェ ノール樹脂架橋があり, 押出機中で PP, EPDM, 架橋剂, オイル等を溶融混練させながら架橋させる．原材料の添加 順序や滞留時間等, 相容化剂の選定によるモルホロジーの 制御に各社それぞれノウハウを有していると考えられる. インパネ・ドアトリムの表皮材, ウェザーストリップ等の ボディーシーリング材，ステアリングブーツ，エアダクト， エアバックカバー等の自動車用途, 家電用ホース, 機器内 配線や電源コード被覆材, 土木・建築用途等が主用途 $3,4,8)$ である。

\subsection{2 リアクターTPO}

リアクターTPO は重合時にEPM等のゴム成分を導入し た直後重合型の軟質 $\mathrm{PO}$ 系樹脂である.PPブロックコポ リマーと製法上の区別はないが，リアクターTPOでは 40 〜 50\%以上，PPブロックコポリマーでは 5 20\%程度の ゴム量のものが多い.

主用途はフィルム・シートや自動車向けなどであり, 脱 塩ビ化のための柔軟性の高いリアクターTPOの需要が高
くなってきている.

\section{2 .3 樹脂改質用オレフィン系エラストマー}

樹脂改質用オレフィン系エラストマーとしては，世界的 にはダウケミカルの「エンゲージ」, 国内は三井化学「夕 フマー」がトップであり，他にJSRの EBM・EPRなどが ある．樹脂改質用オレフィン系エラストマーの主用製品の 概要 ${ }^{4)}$ を表 4 に示す.

最近の素材開発動向としてメタロセン等の触媒技術を用 いた新製品が多く市場に出ている. 三井化学「タフマー $\mathrm{XM} 」$ はチーグラー・ナッ夕触媒系の「タフマーXR」に 比べて分子量分布とコモノマー分布が均一であり, 低融点 化が達成され低ヒートシール化が可能となり, フィルム用 途に展開されている ${ }^{4)}$. また同社の「ノティオ」もメタロ センを用い，結晶と非晶をナノオーダーに構造制御してお り, ゴム弾性や柔軟性と耐熱バランス, PPへの相容性等 に優れることが特徴である. 各種フィルムや自動車材料に 展開している．ダウケミカルはInfuse熱可塑性オレフィ ンブロックコポリマー $(\mathrm{OBC})$ を開発中 $\left.{ }^{11} 10\right)$ である. 本工 ラストマーは直鎖状ポリエチレンブロックとエチレン-オ クテンのソフトセグメントから成り, 高融点 (約 $120^{\circ} \mathrm{C}$ ) と 高結晶化温度 (約 $100^{\circ} \mathrm{C}$ ) を有する. しかし OBCの $T_{\mathrm{g}}$ は工 チレンのランダムコポリマーに似ており，このため同じょ うな低温延性を有する．また低圧縮永久ひずみと良耐摩耗 性も特徴であり, 自動車用途への展開が期待 ${ }^{10)}$ される.

住友化学も新触媒技術を用いた PP系完全非晶性の軟質

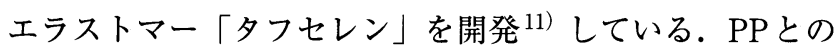
相容性に優れ, PP の延伸加工特性, 耐摩耗性, 透明性等 の改質が可能である. 粘着性, フィラー受容性にも優れる ことから, 粘着剤, 難燃配合等にも応用されている.

\subsection{T-PVC}

T-PVCには(1)高重合度PVCの微結晶と(2)重合で生成す 
る部分架橋構造を拘束相とするタイプ12) がある.

用途は自動車の内外装向けが主力製品である. インパネ についてはT-PVCの有する耐傷付性や質感, ソフト感か ら上級者向けに使われていた ${ }^{9)}$ が，ここ数年はスラッシ 工成形用の TPUパウダーが開発・上市され, また普及車 ではTPOの使用も増え, T-PVCの需要は低調となって いる ${ }^{3,4)}$ (図 $1-3$ 参照). 土木建築分野はパッキン類, サ ッシ用機密材等の耐水性とコストが要求される製品向けに 使用されている。電線被覆は艶消し, 柔軟性, ソフト感な どから VCTケーブルやパソコン周りのケーブルに使われ ている.

技術動向 ${ }^{8)}$ として $\mathrm{PVC} / \mathrm{NBR}, \mathrm{TPV} / \mathrm{PVC}$ ブレンド, TPU/PVC, PVC/EVA-g-エチレン・アクリレートのよ うな PVCとの複合化・アロイ化により耐熱性・耐候性・ 耐油性・艶消し外観・低圧縮永久ひずみを改善したものが 多く開発されている.この場合, PVCが拘束相・ゴム弾 性はゴムやTPEで発現させる，今後, 複合化により一層 高性能化が進むと思われる。

\subsection{TPU}

TPUはイソシアナート (TDI (トリレンジイソシアナー ト), MDI(ジフェニルメタンジイソシアナート), $\mathrm{HDI}(ヘ$ キサメチレンジイソシアナート)等)とポリオール (PTMG (ポリオキシテトラメチレングリコール, PPG(ポリオキシ プロピレングリコール)) やポリエステルジオール (アジペ ートタイプ, ラクトンタイプ), ポリカーボネートジオー ルなどのソフトセグメントで構成されたTPEである．高 機械強度, 低温特性, 耐久性, TPE中で最高の耐摩耗性 や極性ポリマーとの易ブレンド性，圧縮永久ひずみに優れ る.

TPU市場は順調に推移し，世界で357,000t，国内では $15,000 \mathrm{t}^{13)}$ であり，国内で $5 \%$ 程度の成長を示している (図 $1-3$ ). 特に中国・インド等での海外需要が高く, ア ジアへの輸出が好調 3 , 4) である.

TDI 等の芳香族イソシアナートタイプの TPUは紫外線 で劣化, 黄変する. 各社はHDI 等の特殊なイソシアナー 卜基を導入した無黄変グレードを上市し, 自動車用途, OA 機器ハウジングへの展開が進んでいる. 自動車のイン パネ表皮での脱塩ビ化の動きを受けて，スラッシュ成形用 の TPUパウダーやスプレー成形に使用する熱硬化性 TPU が開発された.パウダーには真球状タイプとTPUペレッ トを冷凍粉砕する夕イプがある.押出分野では耐圧ホース, チューブ類, フィルム・シート向けはエアマット, 健康器 具等の介護関連製品向け需要が堅調に推移している.

TPUとSEBS とのブレンドやシリコーンをソフトセグ メントに導入したタイプ1,14）も上市されている.

\subsection{TPEE}

TPEEはハードセグメントにPBT, ソフトセグメント にPTMG, PPGまたは脂肪族ポリエステル(ポリラクトン 等)が使用される.

他 TPEに比べ, 耐熱性, 耐油性, 耐衝撃性, 屈曲疲労 性に優れ，射出成形性や着色性が良好である。

TPEE市場は自動車への堅調な採用や電気・電子や日用

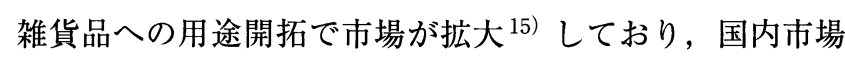
は年率 7 〜 $10 \%$ 増の推移が見込まれる. 東レ・デュポン 「ハイトレル」と東洋紡「ペルプレン」でシェアの $90 \%$ 以 上を占めているが，三菱化学の「プリマロイ」が雑貨分野 でシェアを伸ばしている，本製品はTPEEをマトリック スとし，TPSをドメインとすることで柔軟性と圧縮永久 ひずみを持たせることを可能 ${ }^{4)}$ とした. 東レ・デュポン でも架橋特殊ゴムをTPEEに分散させた柔軟グレードを ラインアップしている。また同社はデュポンが開発した ETPVの市場展開を図っている. ETPVはTPEEマトリク スに架橋型高性能ゴムを分散させた動的架橋型TPEEで あり, TPEEの 50\%の圧縮永久ひずみ, 硬度 60 〜0Aで $150^{\circ} \mathrm{C}$ の耐熱性が有るとされる.

TPEE は他 TPEやゴムとの複合化による新材料開発に より今後も市場を伸ばしていくと考えられる.

\subsection{TPAE}

TPAEはハードセグメントにPA6，12，66，11，12等 のポリアミド, ソフトセグメントにPTMG, PPG等から なるブロック共重合体である. ハードセグメントの異なる タイプが種々開発されている，TPAEのここ数年の国内 需要は前年並みの水準にとどまっているものの, スポーツ シューズやスキーブーツ向けなどの販売がアジア向けに伸 びており，2005年は $1590 \mathrm{t}$ と前年比 $5 \%$ 増で推移 ${ }^{3,4)}$ して いる. 家電・OA 機器, スポーツ・レジャー, 改質剤の 4 大用途にそれぞれ $25 \%$ 程度ずつを占める．特に優れた消 音特性や耐摩耗性, 寸法安定性のため, 複写機やプリンタ 一, VTR，MD，DVD等の駆動部ギア等に採用されてお り, 特に改質剂分野への展開も期待されている.

\section{3. 今後の展望}

TPEの国内需要の成長はやや落ち着いた感があるが, 世界レベルでみれば高成長は今後も続く、メタロセン等の 触媒技術を利用したブロックの導入や立体規則性が精密に 規制されたTPOは今後も次々と出現してくると思われる.

また, 他樹脂・他 TPE・ナノフィラー・機能性フィラ 一との複合化TPEは一層用途開拓も進むだろう.

今後の熱可塑性エラストマーの展開の一端として(1)メ夕 ロセン等の新触媒を用いた新しいTPEの開発, (2)後架橋 による高性能化, (3)異種材料との複合成形, (4)樹脂ブレン ドの創出, (5リサイクル・再利用の活用, 6ナノコンポジ 
ット等が成長すると最近の秋葉の著書 ${ }^{8)}$ に書かれている.

(1)については既に述べた. (2)は分子末端や主鎖に反応基 を導入した熱可塑性エラストマーやPEが実用化されつつ あり，水架橋や光反応性により後架橋したエラストマーが 電線用途やチューブ・パイプ類, 感光材等に使われている. 今後の更なる成長が期待される. (3)の異種材料との複合化 はETPVやsuper-TPV, TPU/TPS コンパウンド等が相 当する. 動的架橋技術やリアクティブプロセッシング，相 容化技術がキーテクノロジーとなる．中でもTPVは種々 の素材を組み合わせ，今後も高性能・高機能化が進む. Super-TPVは, シリコンゴム, アクリルゴム, アイオノ マー, ニトリルゴム等をベースにした材料が開発されてい る.これらはTPEE, エンジニアリンプラスチック等のド メインの中に動的架橋でゴムを分散したものであり，耐熱 性や耐油性が著しく優れる。最近，マトリクスにPA6, ドメインがアクリルゴムの TPVが日本ゼオンから開発1,16) された．耐グリース性でTPEEをしのぐ性能が報告され ている. 高スチレン HSBRもエンプラやTPV と複合化し, 耐摩耗性，制振性の軟質材料として用いられている。

(3)(4)(5)(6)重要な役割を果たす相容化剂が各社から上市 されているが，中でも変性TPSが期待されている．既存 変性タイプは官能基が主鎖にグラフトしたものである．一 方, 末端変性タイプはアミノリチウム開始剤やリビングア ニオン重合の末端変性技術により得られたSBSやSEBS 等 である.SEPSの分子末端水酸基を利用してポリウレタン をブロック化したものも開発されている.

これら変性TPSはリアクティブプロセッシングによっ てポリアミドやPET, ポリ乳酸等の極性樹脂の改質，ポ リ乳酸 $/ \mathrm{PP}$ ，ポリ乳酸 $/ \mathrm{PC}, \mathrm{PP} / \mathrm{PMMA}$ ，ポリオレフィ ン / TPU等の各種コンパウンドの相容化剤, TPV生産時 の相容化剤，新しいブロックポリマー (TPE)の創生に使 える可能性 ${ }^{17)}$ がある. また，無機フィラーや機能性フィ ラーの高分散にも有効であり，機能性エラストマーの設計 にも展開されるだろう。さらに変性TPSと有機化クレー 等のナノコンポジットも各種報告されている. エラストマ 一ナノコンポジットは樹脂ブレンドの表面特性や剛性を改 良 ${ }^{18)}$ する。あらかじめエラストマーナノコンポジットの マスターパッチを作っておき，それを樹脂ブレンドするこ とで自動車外装材料等への実用化が待たれる。

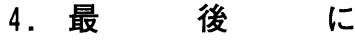

以上，TPEの発展と展望について述べたが，片寄った 内容となったことをお詫びしたい. 今後はますます樹脂， 他 TPE との複合化が進み, 従来法で分類できない高機 能・高性能のTPEが次々と出現してくるだろう，紙面の
都合で割愛したが，生分解性のTPEや植物由来のTPEも 開発が進んでおり，コストが下がれば急激に用途も増えて いくものと考えられ，期待される.

\section{References}

1 ) Modern Plastics Worldwide, World Encyclopedia, 107 (2006)

2) Furukawa, J. : Gomu Gizyutsu Forum Eds. : "Tenkanki no Koubunshi Kougyou”, Posuty Corp., Tokyo, p. 80 (1987)

3 ) Yano Research Institute Ltd. Eds. : "2004 Nenban Netsukasosei Elastomer Sijou no Tenbou to Senryaku", Yano Research Intutitute Ltd., Tokyo (2004)

4 ) Yano Research Institute Ltd. Eds. : "2006 Nenban Netsukasosei Elastomer Sijou no Tenbou to Senryaku", Yano Research Institute Ltd., Tokyo (2006)

5 ) Polyfile, 42(496), 52 (2005)

6) ibid, 42 (496), 57 (2005)

7 ) Takamatsu, H. : JETI, 54(12), 96 (2006)

8 ) Akiba, M. : "Netsukasosei Elastomer no Subete", Kougyou Chousa Kai, Tokyo (2003)

9) Kusakawa, N.: "Jidousha to Koubunshi”, CMC, Tokyo (2006)

10) Plastic Technology, Feb., 23 (2007)

11) Polyfile, 42, 496, 50 (2005)

12) Yamabe, R. : JETI, 54(12), 107 (2006)

13) Kakinuma, Y. : ibid, 54(12), 113 (2006)

14) Watanabe, T. ; Komatsu, K. : "Yasashii Gomu Elastomer", Sankoshuppan, Tokyo (1998)

15) Kawaguchi, Y. : JETI, 54(12), 81 (2006)

16) Zama, Y. : Nippon Gomu Kyokaishi, 79, 257 (2006)

17) Kato, K. ; Fujiwara, M. ; Araki, Y. : JETI, 54(12), 85 (2006)

18) Nishi, T. ; Izawa, S. ; Akiyama, S. : Koubunshi Gakkai Koubunshi ABC Kenkyuukai Eds., "Polymer ABC Handbook", NTS, Tokyo (2001)

\section{日本語表記参考文献}

1) Modern Plastics Worldwide, World Encyclopedia, p. 107 (2006)

2 ）古川淳二監修，ゴム技術フォーラム編集：転換期の高分子材料, ポスティコーポレーション, 東京, p.80 (1987)

3 ) 矢野経済研究所編集：2004年版 熱可塑性エラストマー市場の 展望と戦略, 矢野経済研究所, 東京 (2004)

4 ）矢野経済研究所編集：2006年版 熱可塑性エラストマー市場の 展望と戦略, 矢野経済研究所, 東京 (2006)

5 ) ポリファイル, 42(496), 52 (2005)

6) ポリファイル, 42 (496), 57 (2005)

7 ) 高松秀雄：JETI, 54(12), 96 (2006)

8 ) 秋葉光男：熱可塑性エラストマーのすべて, 工業調查会, 東京 (2003)

9 ）草川紀久：自動車と高分子材料，シーエムシー，東京 (2006)

10) Plastics Technology, Feb., p. 23 (2007)

11）ポリファイル，42(496), 50 (2005)

12）山部良一：JETI, 54(12), 107 (2006)

13）垣沼幸則：JETI，54(12)，113 (2006)

14）渡邊隆, 小松公栄：やさしいゴム・エラストマー, 三光出版, 東京 (1998)

15）川口泰治：JETI，54(12)，81（2006）

16）座間義明：日本ゴム協会誌，79，257（2006）

17）加藤清雄，藤原正裕，荒木祥文：JETI，54(12)，85 (2006)

18）西敏夫, 伊澤慎一, 秋山三郎監修; 高分子学会 高分子 $\mathrm{ABC}$ 研 究会編集：ポリマーABCハンドブック, NTS, 東京 (2001) 